\title{
Comparative Morpho-Biochemical Responses of Sunflower Lines Sensitive and Tolerant to Water Stress
}

\author{
Andrea Andrade*, Ana Vigliocco, Sergio Alemano, Analía Llanes, Guillermina Abdala \\ Departamento de Ciencias Naturales, Facultad de Ciencias Exactas, Físico-Químicas y Naturales, Universidad Nacional de Río \\ Cuarto, Córdoba, Argentina. \\ Email: ${ }^{*}$ aandrade@exa.unrc.edu.ar
}

Received November $10^{\text {th }}, 2013$; revised December $12^{\text {th }}, 2013$; accepted December $25^{\text {th }}, 2013$

Copyright (C) 2013 Andrea Andrade et al. This is an open access article distributed under the Creative Commons Attribution License, which permits unrestricted use, distribution, and reproduction in any medium, provided the original work is properly cited.

\begin{abstract}
Water stress is likely the most important factor that adversely affects plant growth and development. In our study two inbred lines of sunflower (Helianthus annuиs L.) with contrasting behavior to water deficit, the inbred lines B59, sensitive, and B71, tolerant, were subjected to water stress and compared in terms of growth parameters, relative water content, photosynthetic pigments and osmo-compatibles contents. Mannitol treatment generated a moderate water stress which resulted in a relative water content decline in both lines. In aerial part of B59 and B71 stressed-seedlings, a dramatic reduction of osmotic potential was observed, although in B71 the osmotic potential was 1.8-fold lower than in B59. The B71 line recovered the osmotic potential to control values after $8 \mathrm{~d}$ of re-watering. Several morphological parameters were altered by the water stress. Shoot and root relative fresh weight decreased in both lines under water stress, although B71 showed a minor drop. However, the root was less affected than the shoot in stress condition and recovery period. Water stress was affected in a greater proportion shoot dry weight $(D W)$ than root $D W$ in $\mathrm{B} 59$ and $\mathrm{B} 71$ lines. Nevertheless, a significant increase in root $D W /$ shoot $D W$ ratio was observed in stressed seedlings. A higher reduction in the individual leaf area was observed in B71 line under stress. The basal chlorophyll content was higher in the tolerant line B71 than in the sensitive B59, and carotenoids showed a high content in B71 control and stressed seedlings. Under water stress, the aerial and root proline content increased in the tolerant B71 line. Glycinebetaine decreased significantly in the aerial part of both lines in response to water stress indicating that this compound is not the main osmo-regulator. In conclusion, B71 has suitable mechanisms to enable it to respond more effectively to moderate water stress.
\end{abstract}

Keywords: Growth Parameters; Osmo-Compatibles Solutes; Photosynthetic Pigments Sunflower; Water Stress

\section{Introduction}

Water stress is one of the most important factors of abiotic stresses that affect on growth and yield of plants worldwide [1,2]. A drop in water potential induces a variety of metabolic, morphological, and/or physiological responses, including reduction in the vegetative growth [3], generation of eactive oxygen species [4], accumulation of osmotically active solutes [5], changes in endogenous levels of plant hormones [6-8], and altered expression of stress responsive-genes [9-11]. Several of these responses are triggered directly by altered water status in plant tissues.

Plant responses to water stress vary depending on intensity and duration of stress, plant species, and devel-

"Corresponding author. opment stage [12]. Seed germination is the earliest and most sensitive stage in the plant life cycle, and establishment of seedlings is highly susceptible to water deficit and other environmental stresses [13]. In sunflower (Helianthus annuus L.), low water availability in the soil has a negative impact on yield, which depends on the plant ontogenetic stage for which this occurs. This crop is better able to tolerate drought than many agricultural crop species, and is often cultivated in arid regions. However, like other oil crops, sunflower is sensitive to water deficit at the germination stage [14].

Analysis of morphological traits is useful for studying of plant adaptations to environmental stresses such as water deficit. In lentil (Lens culinaris Medic) and grass pea (Lathyrus sativus L.), water stress induced changes in 
growth traits such as plant height, number of primary branches and leaves per plant, dry weight of shoot and roots. Both crops reduced these growth parameters after plants were subjected to 20 days of water stress [15]. Similarly, [16] observed in sensitive maize genotype a decrease of stomatal conductance and a slighter decrease in relative water content. In contrast, the tolerant genotype maintained open stomata and active photosynthesis, even under dehydration conditions.

Among the parameters responding to stress treatment, rapid accumulation of free proline (PRO) content is one of the significant events in plants. The accumulation of cytosolutes, particularly PRO, should avoid the detrimental effects of low osmotic potential of the cells without interfering with protein synthesis. Besides their roles in osmotic adjustment, they may protect membranes from damages and stabilize the structures and activities of proteins and enzymes $[17,18]$.

Likewise, PRO accumulation in many plants under stress has been correlated with stress tolerance [19]. In this sense, it has been reported that PRO improves drought resistance in sunflower [20], peper [21], maize [22], rice and barley [23]. In addition, it has been reported that glycinebetaine (GB) is an effective osmoprotectant which accumulates in a number of plants under drought stress $[19,24]$ thereby playing a vital role in plant tolerance to drought [25-27]. Positive effects of GB foliar spray on yield and yield component in plants grown under water limited environment has been reported in different crops such as rice [28], sunflower [29] and common bean [30].

Sunflower yield reduction and changes in growth parameters, relative water content $(R W C)$, lipid peroxidation, PRO content and activities of the antioxidant enzymes were reported after drought application [31,32]. As a result, it has become important to elucidate drought tolerance mechanism of sunflower to improve its agronomic performance to obtain more resistant cultivars.

In the present study, we investigated to what extent moderate water stress affects growth parameters, $R W C$, photosynthetic pigments and osmo-compatibles contents in two sunflower lines of contrasting behavior to water deficit.

\section{Materials and Methods}

\subsection{Plant Material}

Sunflower seeds (Helianthus annuus L., Asteraceae) of sensitive B59 and tolerant B71 inbred lines, supplied by MSc. Daniel Alvarez, were sown in an experimental field of EEA-INTA Manfredi (31 $51^{\prime} 9.00^{\prime \prime}$ South latitude and $63^{\circ} 44^{\prime} 55.91^{\prime \prime}$ West longitude), Argentina.

\subsection{Germination Assay}

Hundred sunflower seeds of B59 (sensitive to water stress) and B71 (tolerant to water stress) lines were surface sterilized with $10 \%$ sodium hypochlorite solution for $5 \mathrm{~min}$, washed three times with distilled water, and then sown in $19 \times 26-\mathrm{cm}$ pot between two filter paper towels moistened with $50 \mathrm{ml}$ deionized water. The pots were kept under controlled growth conditions in a walk-in rooms GR48 (Conviron Winnipeg, Canada) and a cycle of $16 \mathrm{~h} \mathrm{light}\left(200 \mu \mathrm{mol} / \mathrm{m}^{2} / \mathrm{seg}\right)$, at $28^{\circ} \mathrm{C}$ and $70 \%$ relative humidity, and $8 \mathrm{~h}$ dark, $20^{\circ} \mathrm{C}$ and $80 \%$ relative humidity, during $48 \mathrm{~h}$. To avoid any effect due to the position of a pot in the chamber, each pot was rearranged at random every day. The seeds were assumed to have germinated when the radicle protruded through all the covering layers (testa and pericarp). At $48 \mathrm{~h}$, the $50 \%$ of germinated seeds with a length root within the range $(X \pm$ $\delta$ ) were harvested. The assay was performed for quintupled.

\subsection{Early Growth Assay, Water Stress Treatment, and Recovery Period}

The germinated seeds were immediately transferred to 31 $\times 18 \times 10 \mathrm{~cm}$ trays (50 seeds per tray) containing fine sand. At time of planting the water content was $60 \%$ field capacity (FC). Each tray was placed inside a nylon bag open at the top. Then, trays were placed in a growth chamber programmed as described above. Mannitol (400 $\mathrm{mM}$ ) was used as a drought stimulator, and a moderate water stress level of $-0.989 \mathrm{MPa}$ was developed by dissolving $7.28 \mathrm{~g}$ of mannitol per $100 \mathrm{ml}$ distilled water. From the 4th day of planting in sand, and when seedlings were 6 day-old, water stress was applied by mannitol irrigation during 14 day-time till moderate water stress was reached. Controls plants (control) were grown continuously with normal irrigation (Hoagland's solution, $50 \%$ of full-strength). Irrigation with Hoagland's solution or mannitol was done every 3 days till the end of the experiment. The optimal harvest time was determined when wilting visual symptoms were observed (water stress treatment-stressed).

To evaluate plant recovering subsequent to water stress, after 5 days of irrigation with mannitol seedlings were kept in optimal growth conditions, i.e., re-watered with Hoagland's solution during 3, 5 and 8 days after rewatering ("recovery period") $(R W 3 \mathrm{~d}, R W 5 \mathrm{~d}$ and $R W 8 \mathrm{~d})$ till the end of the experiment.

Different morpho-physiological and biochemical parameters were studied at harvest. Each sample consisted of 15 plants.

\subsection{Measurement of Morpho-Physiological Parameters}

After harvest, fifteen plants of each condition (control, stressed and $R W$ ) were separated into aerial part and roots and cleaned with distilled water. Fresh weight $(F W)$ 
of aerial and root parts was recorded. Samples were then dried in an oven at $60^{\circ} \mathrm{C}$ until constant dry weight $(D W)$ was obtained. $F W$ and $D W$ were expressed in $\mathrm{g} \cdot$ plant $^{-1}$. Aerial part and root $F W$ and $D W$ were recorded at day 18 (end of the experiment) and at day 3, 5, and 8 of the recovery period; $F W$ was expressed as percentage of control value. Sampling for individual leaf area determination consisted of selecting the first pair of leaves of the same fifteen seedlings. For each sampled leaf, length in millimeters was measured as the distance from the apex to the base of leaf blade (point of attachment of petiole), and leaf breadth in millimeters was measured across the widest portion of the blade at a right angle to the measurement for length. The area in square millimeters of each individual leaf was then estimated according to the equation of Schneiter (1978) [33].

The $R W C$ was estimated according to Turner (1981) [34] and evaluated from the equation given below:

$$
R W C(\%)=[(F W-D W) /(T W-D W)] \times 100,
$$

where $F W=$ fresh weight, $T W=$ weight at full turgid, measured after floating leaf discs in distilled water inside a closed Petri dish for $24 \mathrm{~h}$ in dark at room temperature, and $D W=$ weight estimated after drying the leaf discs at $70^{\circ} \mathrm{C}$ until a constant weight was achieved. Leaf discs were always collected from the mid section of either seedling in order to minimize age effects. The experiments were performed in quadruplicate.

For measurement of osmotic potential, $300 \mathrm{mg}$ of leaves or roots were placed in tubes and frozen at $80^{\circ} \mathrm{C}$ for $24 \mathrm{~h}$, thawed and centrifuged at $8000 \mathrm{~g}$ for $30 \mathrm{~min}$. A 150 aliquot of each sample was placed in a capsule and osmotic potential was measured with a freezing point osmometer ((Semi Micro K-7400; Knauer, Berlin, Germany) [35], 2008). Roots were previously washed three times with abundant deionised water, checking that no ions were detected in the final wash.

Leaf appearance rate was calculated by the following equation, and expressed as number of leaf/day

$$
\text { Leaf appearance rate }=1 / \text { phyllochron, }
$$

phyllochron was estimated from the Thermal time using the formula:

$$
\text { Thermal time }\left({ }^{\circ} \mathrm{Cd}\right)=\sum\left[\left(T_{\max }+T_{\min }\right) / 2-T_{B}\right]
$$

where, $T_{\max }=$ daily maximum air temperature, $T_{\min }=$ daily minimum air temperature, and $T_{B}=$ base temperature of $6^{\circ} \mathrm{C}$.

\subsection{Measurement of Biochemical Parameters}

2.5.1. Estimation of Photosynthetic Pigment Contents Levels of chlorophyll $a$ and $b$ were quantified by the conventional method, using the corresponding extinction coefficients for calculations. Fresh leaves $(100 \mathrm{mg})$ were ground in a mortar and left in $80 \%$ acetone $1 \mathrm{~h}$ at $4^{\circ} \mathrm{C}$ for extraction, and their levels were expressed as milligrams/gram $F W$. After centrifugation, absorbance of the supernatant was measured at $650 \mathrm{~nm}$ (for chlorophyll $a$ ) and $665 \mathrm{~nm}$ (for chlorophyll $b$ ) using a spectrophotometer (Helios Gamma, Thermospectronic, UK). Carotenoids content were calculated using the formula of Lichtenthaler and Wellburn (1983) [36].

\subsubsection{Estimation of PRO Content}

The free PRO accumulation was determined from 500 $\mathrm{mg}$ of plant material using the acid-ninhydrin reagent method by Magné and Larher (1992) [37]. The extract was reacted with $1 \%(\mathrm{w} / \mathrm{v})$ ninhydrin reagent in $60 \%(\mathrm{v} / \mathrm{v})$ of glacial acetic acid, which was boiled at $100^{\circ} \mathrm{C}$ for $1 \mathrm{~h}$. After termination of reaction in ice bath, the mixture was extracted with $4 \mathrm{ml}$ of toluene and the optical density was measured at $520 \mathrm{~nm}$. PRO content was determined from a standard curve in the range of $0-1 \mu \mathrm{mol} / \mathrm{ml}$, and expressed in $\mu \mathrm{g} \cdot \mathrm{g}^{-1} \mathrm{FW}$.

\subsubsection{Estimation of GB Content}

Quaternary ammonium compounds (QACs) were extracted and measured as GB equivalents according to Grieve and Grattan (1983) [38]. Fresh and finely ground plant material $(500 \mathrm{mg})$ was mechanically shaken with 3 $\mathrm{ml}$ of deionized water for $24 \mathrm{~h}$ at $25^{\circ} \mathrm{C}$. The samples were then filtered and filtrates were diluted to $1: 1$ with 2 $\mathrm{N} \mathrm{H}_{2} \mathrm{SO}_{4}$. Aliquots $(0.5 \mathrm{ml})$ were kept in centrifuge tubes and cooled in ice water for $1 \mathrm{~h}$. Cold KI- $\mathrm{I}_{2}$ reagent $(0.20$ $\mathrm{ml})$ was added and the reactants $\left(\mathrm{KI}^{-} \mathrm{I}_{2}\right.$ reagent: $15.7 \mathrm{~g} \mathrm{I}_{2}$ $+20 \mathrm{~g} \mathrm{KI}$ were dissolved in $100 \mathrm{ml}$ of distilled water) were gently stirred with a vortex mixture. The tubes were stored at $4^{\circ} \mathrm{C}$ for $16 \mathrm{~h}$ and then centrifuged at $10,000 \mathrm{rpm}$ for $15 \mathrm{~min}$ at $0^{\circ} \mathrm{C}$. The supernatant was carefully aspirated with a fine tipped glass tube. The periodide crystals were dissolved in $9 \mathrm{ml}$ of 1,2-dichloroethane and mixed vigorously. After $2 \mathrm{~h}$, absorbance was measured at 365 $\mathrm{nm}$ using a spectrophotometer (Helios Gamma, Thermospectronic, UK). Reference standards of GB (0 - 10 $\mu \mathrm{g} / \mathrm{ml}$ ) were prepared in $1 \mathrm{~N}_{2} \mathrm{SO}_{4}$, and their content was expressed in $\mu \mathrm{g} \cdot \mathrm{g}^{-1} \mathrm{FW}$.

\subsection{Statistical Analysis}

The experiment was laid out in a randomized block design and each one was performed four times, consecutively ( 2 trays per treatment each time). Each condition (control, stressed and $R W 3 \mathrm{~d}, 5 \mathrm{~d}$ and $8 \mathrm{~d}$ ) was analyzed with at least three replicates, and a standard deviation (S.D.) was calculated. The data were expressed in mean \pm S.D. of three or four replicates. All data were subjected to two-way analysis of variance (ANOVA) to determine differences among conditions for each variable. The significant differences between means were determined 
using Tukey's test at $P \leq 0.05$ level. Data were tested for normality by Kolmogorov-Smirnov test. Variances were homogeneous in all cases. The software employed was Statgraphics Plus, version 3 (Manugistics, Rockville, Maryland, USA).

\section{Results}

\subsection{Effect of Water Stress on Water Relations Parameters}

During the water stress and the recovery period RWC was affected in the sunflower inbred lines (B59, sensitive and B71, tolerant). No significant differences were observed between both lines, but water stress significantly decreased leaf $R W C$, and the reduction was almost the same for the two lines. The significant reduction of $R W C$ in mannitol-treated plants indicated that plants were stressed. Notably, this parameter was not significantly different for either line in response to water stress at any time of the recovery period (Figure 1(a)).

The aerial part of B59 and B71 stressed-seedlings showed the lowest osmotic potential although in B71 the osmotic potential was 1.8-fold lower than in B59. During the recovery period an increase of the osmotic potential

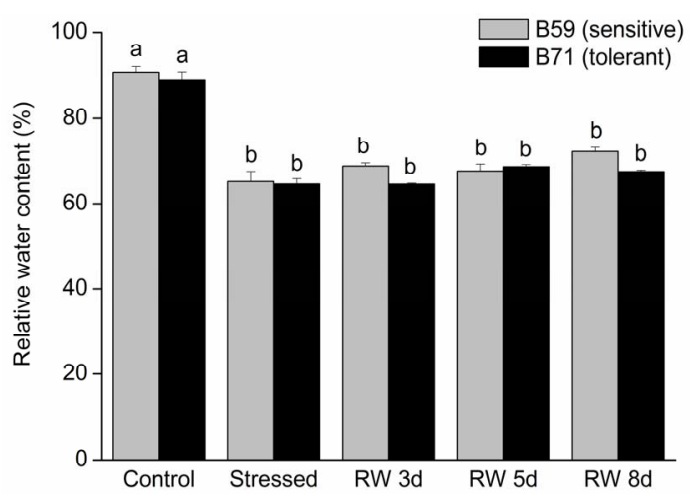

(a) was observed in both lines seedlings. However, at 3 days of re-watering the osmotic potential of the B59 aerial part was similar to that of control, and at 5 and 8 days this parameter remain almost unchanged. Aerial part of B71 line showed an increasing trend in the osmotic potential under re-watering, recovering the control value at 8 day (Figure 1(b)). Contrarily, root osmotic potential of both lines was not modified by water stress or re-watering in comparison to control conditions (Figure 1(c)).

\subsection{Effect of Water Stress on Morpho-Physiological Parameters}

Shoot relative $F W(R F W)$ dramatically decreased under water stress in both lines. During the re-watering B59 and B71 did not modify substantially their $F W$ respect to the stress condition (Figure 2(a)).

Regards to root relative $F W$ of both lines a decreased was also observed under the stress condition. After 5 days of re-watering B59 began to increase slightly although this increase was not significant. Whereas, in B71 after 8 days of re-watering the $F W$ reached the same value than that of stressed root (Figure 2(b)). Comparing both organs, the root was less affected than the shoot in stress condition and recovery period.

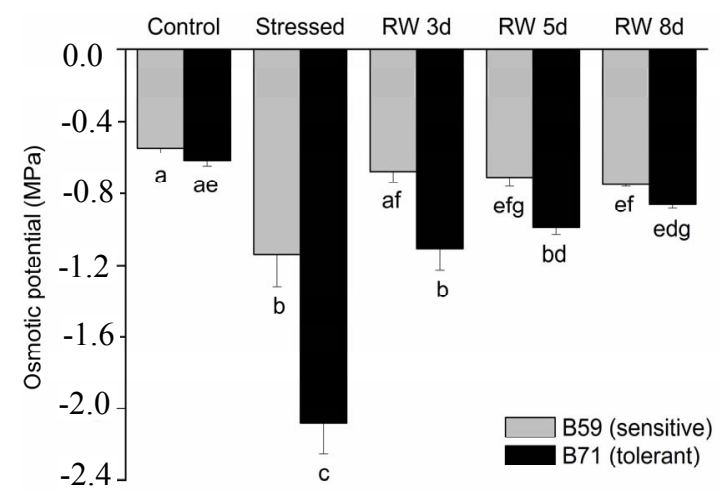

(b)

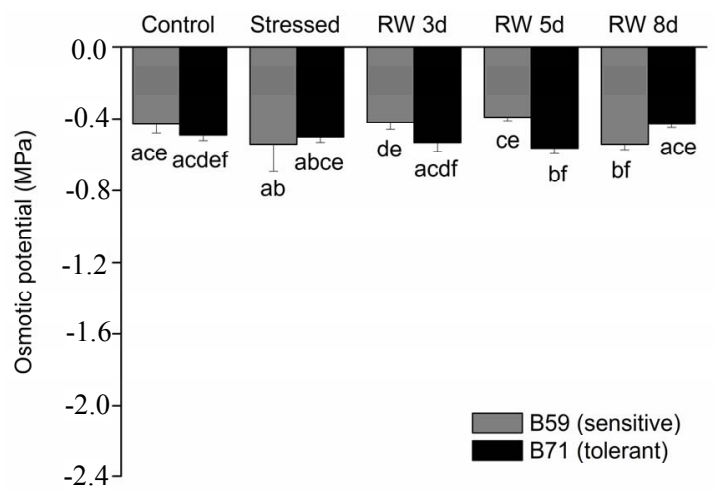

(c)

Figure 1. (a) Leaf relative water content of B59 and B71 sunflower lines grown under water stress and after 3, 5 and 8 days of re-watering ("recovery period") ( $R W$ 3d, $R W$ 5d and $R W$ 8d); (b) Leaf osmotic potential; (c) Root osmotic potential. Data are means of three replicates with SEs. Values with the same letter are not significantly different at $P \geq 0.05$. 


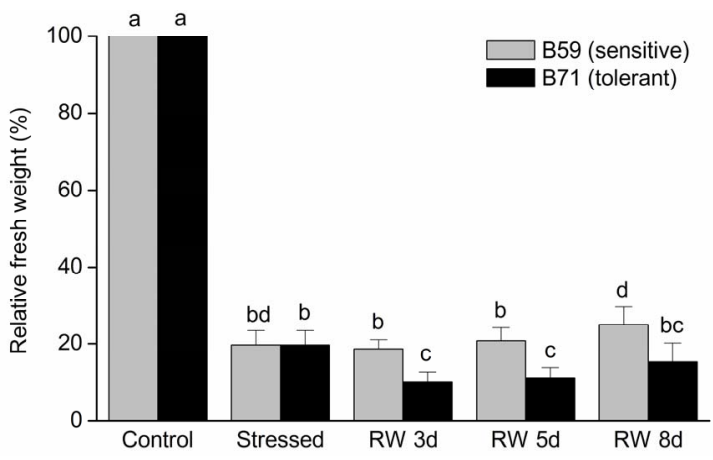

(a)

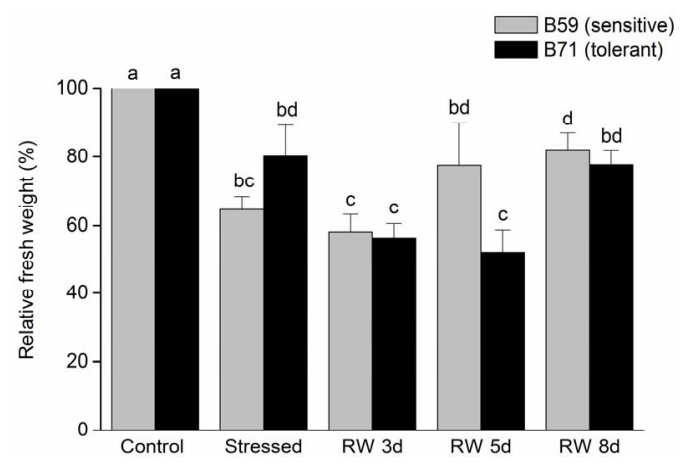

(b)

Figure 2. Relative fresh weight of $B 59$ and $B 71$ sunflower lines grown under water stress and after 3,5 and 8 days of re-watering ("recovery period") (RW 3d, RW 5d and RW 8d). (a) Shoot; (b) Root. Data are means of three replicates with SEs. Values with the same letter are not significantly different at $P \geq 0.05$.

Shoot $D W$ decrease in both lines under water stress compared to control. Shoot $D W$ of stressed B59 dropped 2-fold respect to control, and in B71 the decrease was 3.75 -fold. No differences were observed in shoot $D W$ at any times of re-watering (Figure 3(a)).

In root $D W$ no changes were observed after water stress. After 8 days of re-watering B59 line root $D W$ reached the values of stressed seedlings. In contrast, root $D W$ of $\mathrm{B} 71$ line was higher than water stressed from 5 days of re-watering (Figure 3(b)).

Control seedlings of both lines did not show differences in root $D W /$ shoot $D W$ ratio. However, a significant increased in root $D W /$ shoot $D W$ ratio was observed in stressed seedlings. During the re-watering period, no differences were recorded in the $D W /$ shoot $D W$ ratio of the tolerant B71 line compared with stressed seedlings. In contrast, a significant increase in the $D W /$ shoot $D W$ ratio occurred in the sensitive B59 line during day 5 and 8 of re-watering (Figure 4).

Leaf appearance rate of B59 line was not significantly different between stress condition and recovery period. In contrast, in B71 line a decrease in leaf appearance rate at 3 and 5 days of re-watering was observed, however at 8 days this parameter reached the value of control and stressed seedlings (Figure 5(a)).

Related to individual leaf area, the seedlings of both lines water stressed decrease significantly $(\sim 60 \%)$ respect to the control. Nevertheless, at day 8 of re-watering the leaf area slightly increase in B59 in relation to stressed seedlings. In B71 line, the individual leaf area did not differ between stress condition and recovery period (Figure 5(b)).

\subsection{Effect of Water Stress on PRO Content}

In control condition, PRO content was higher in aerial part of B59 than that of B71. Under water stress PRO content decreased in B59; contrarily an increase was observed in B71 line. During the recovery period PRO de- creased in both lines respect to water stress condition (Figure 6(a)).

In root part, both lines did not significantly differ in their PRO content. On the contrary, under water stress both lines accumulated proline in the roots; although it was more important in B59 $(\sim 120 \%)$ than B71 line $(\sim 60 \%)$ respect to control. During the recovery period proline roots content declined gradually, reaching the values of control after 5 days in B59 line and 3 days in B71 line (Figure 6(b)).

\subsection{Effect of Water Stress on GB Content}

Control aerial part of B59 line had higher GB content than B71. Under water stress, GB decreased significantly in both lines ( $\sim 75 \%$ for B59; $33 \%$ for B 71$)$. At the end of recovery period B71 line reached similar GB content than control, while the content of this solute in B59 increase at day 5 of re-watering without reaching the control value (Figure 7(a)).

Control roots of both lines showed a similar GB content. The water stress condition led to a significantly increase of this compound in B59 line $(\sim 210 \%)$. In contrast, GB content decreased by the stress in B71 line compared to control. At 3 and 5 days of re-watering, B59 roots showed a high content of GB; however, this content abruptly decreased at 8 days. In B71 roots, GB content did not change during recovery period respect to stressed roots (Figure 7(b)).

Regards to photosynthetic pigments, a lower chlorophyll $a$ and $b$ and carotenoids content was registered in B59 line compared to B71. Under water stress, the pigment content was higher in B59 leaves than in control. In contrast, the amount of pigments was lower in B71 stressed leaves than in controls. During the recovery period, especially at 3 and 5 days of re-watering, pigments content remained relatively stable in B59 line. However, at day 8 of re-watering their content increased. Remarkably, during the recovery period pigments of B71 line 


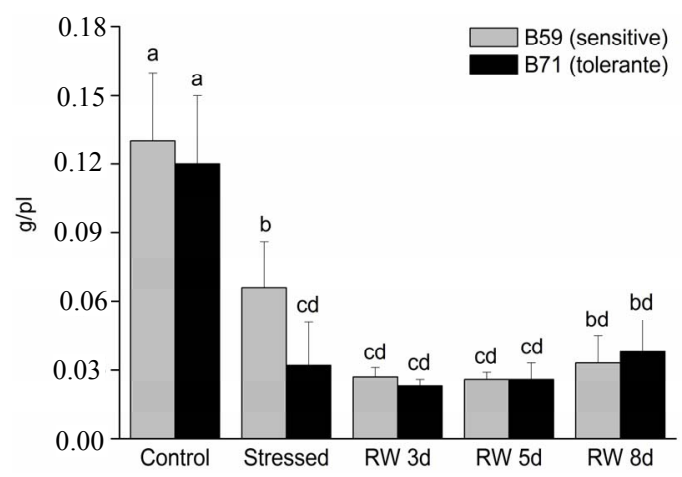

(a)

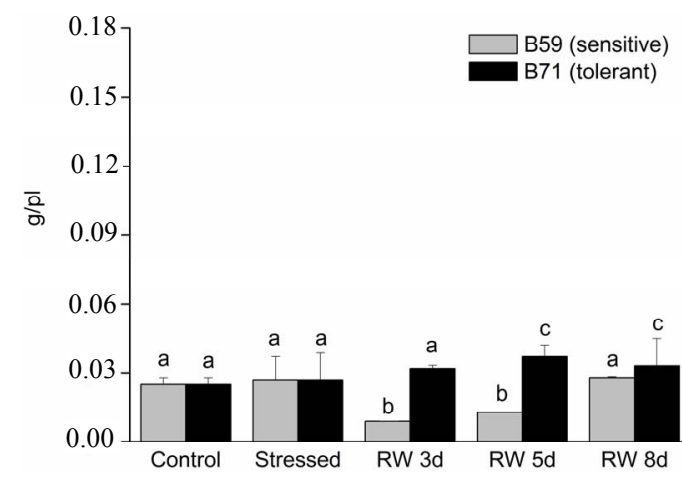

(b)

Figure 3. Dry weight of B59 and B71 sunflower lines grown under water stress and after 3, 5 and 8 days of re-watering ("recovery period") ( $R W$ 3d, $R W 5 \mathrm{~d}$ and $R W$ 8d). (a) Shoot; (b) Root. Data are means of three replicates with SEs. Values with the same letter are not significantly different at $P \geq 0.05$.

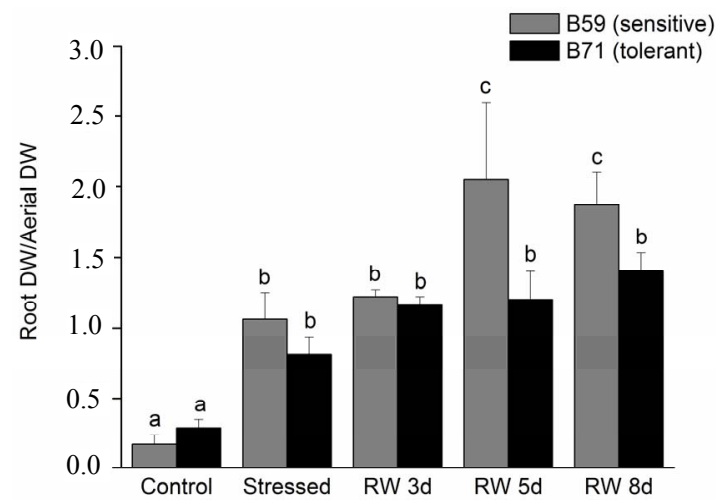

Figure 4. Relationship of root dry weight to shoot dry weight of B59 and B71 sunflower lines grown under water stress and after 3, 5 and 8 days of re-watering ("recovery period") ( $R W 3 \mathrm{~d}, R W 5 \mathrm{~d}$ and $R W$ 8d). Data are means of three replicates with SEs. Values with the same letter are not significantly different at $P \geq 0.05$.

reached similar values of controls. Notably, higher carotenoids content was recorded in B71 line respect to B59 in all conditions experienced (Table 1).

\section{Discussion}

Water deficit is one of the major abiotic stresses, which adversely impacts crop growth and yield. The plant responses to water stress differ significantly at various organizational levels depending upon intensity and duration of stress as well as plant species and its stage of growth $[39,40]$. Among the crops, sunflower is deeprooted crop that has been shown to deplete available soil water. This makes sunflower more tolerant to short periods of water stress [41].

In this study, we observed several differences between both sunflower inbred lines, B59 (sensitive to water stress) and B71 (tolerant), to brief period of water stress. It is known that drought directly affects plant growth and productivity by altering their water status. Among the methods used to characterize internal plant water status under drought conditions, the $R W C$ was used successfully to identify drought resistance in sunflower [42], among other species. Irrigation for $14 \mathrm{~d}$ with mannitol generated a moderate water stress which resulted in a $R W C$ decline in both examined lines. This finding agrees with reports of Angadi and Entz (2002) [42] and Mokhtar Ghobadi et al. (2013) [43] in dwarf hybrids and dwarf open pollinated cultivars of sunflower.

The dramatic reduction of osmotic potential in aerial part of B71 line in response to water stress indicated the ability of leaves to maintain turgor through osmotic adjustment. Several investigations noted that osmotic adjustment is associated with drought tolerance in crop plants, including sunflower [44]. In addition, Ashraf and Foolad (2007) [19] reported that lower osmotic potential has been correlated with solutes accumulation in many plant species under stress, and it is generally higher in stress-tolerant than in stress-sensitive plants, as seems to occur in the PRO content of B71 tolerant sunflower line in response to water stress. Moreover, the recovery of the osmotic potential to control values after $8 \mathrm{~d}$ of re-watering could be also related to PRO content detected at the same time.

It has been well established that water stress is a very important limiting factor at the initial phase of plant growth and establishment. In B59 and B71 lines, several morphological parameters were altered by the water stress. A common adverse effect of water stress on crop plants is the reduction in fresh and dry biomass production [45]. Diminished biomass due to water stress was observed in almost all genotypes of sunflower [46]. However, some genotypes showed better stress tolerance than the others. In our case, the moderate water stress negatively affected the aerial $R F W$ in the same way for both lines, i.e., regardless to their differential sensitivity to stress. Whereas the greater root $R F W$ decrease in B59 line could reflect its sensitivity to a moderate water defi- 


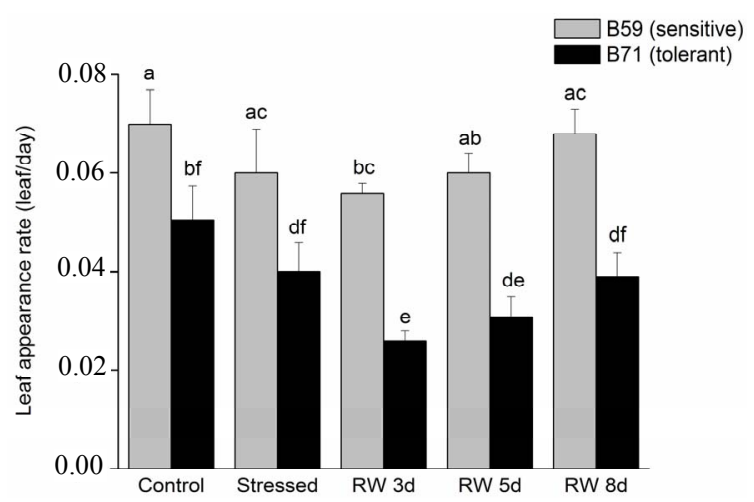

(a)

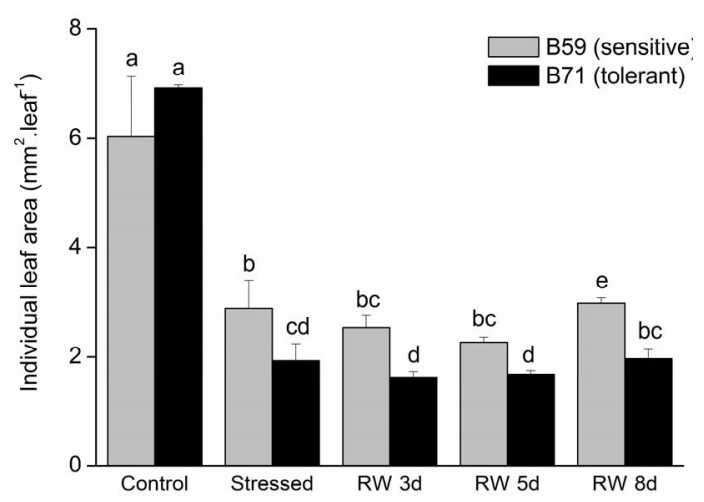

(b)

Figure 5. (a) Leaf appearance rate of B59 and B71 sunflower lines grown under water stress and after 3, 5 and 8 days of rewatering ("recovery period") ( $R W$ 3d, $R W 5 \mathrm{~d}$ and $R W$ 8d); (b) Individual leaf area. Data are means of three replicates with SEs. Values with the same letter are not significantly different at $P \geq 0.05$.

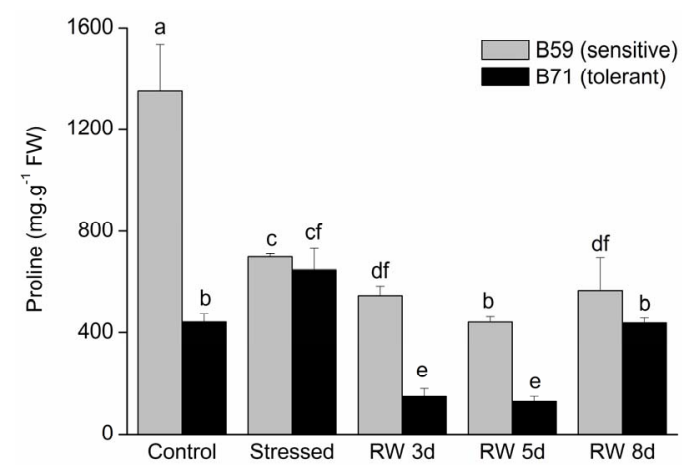

(a)

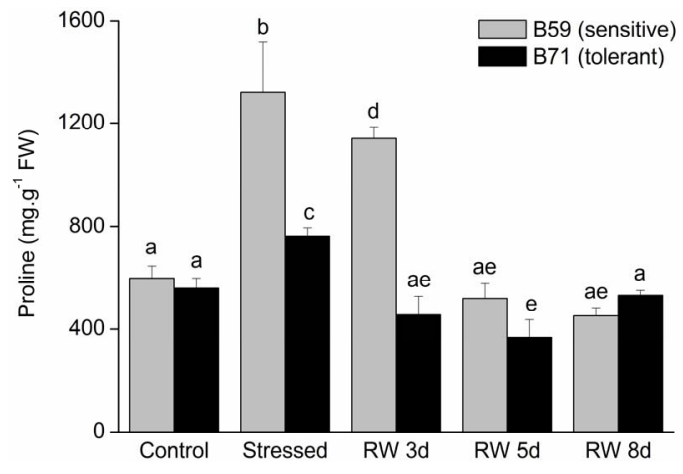

(b)

Figure 6. Proline content of B59 and B71 sunflower lines grown under water stress and after 3, 5 and 8 days of re-watering ("recovery period") ( $R W$ 3d, $R W 5 \mathrm{~d}$ and $R W$ 8d). (a) Aerial part; (b) Root. Data are means of three replicates with SEs. Values with the same letter are not significantly different at $P \geq 0.05$.

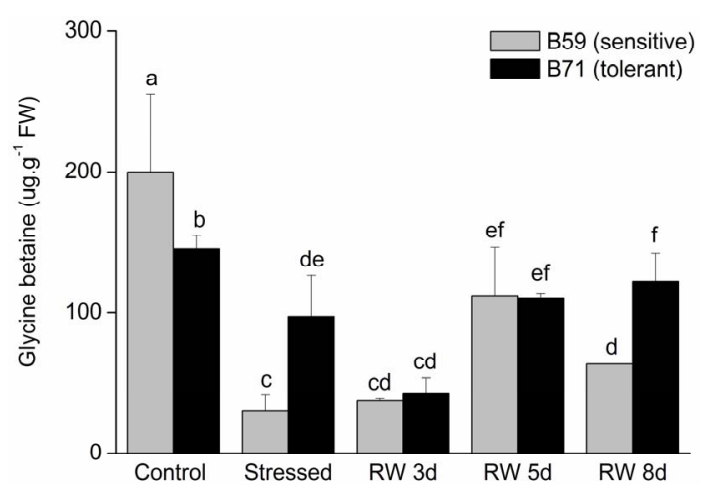

(a)

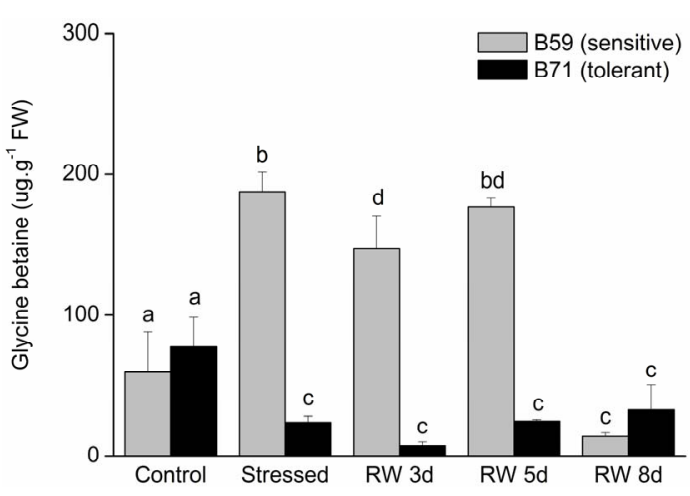

(b)

Figure 7. Glicynebetaine content of B59 and B71 sunflower lines grown under water stress and after 3, 5 and 8 days of re-watering ("recovery period") ( $R W$ 3d, $R W$ 5d and $R W$ 8d). (a) Aerial part; (b) Root. Data are means of three replicates with SEs. Values with the same letter are not significantly different at $P \geq 0.05$.

cit. Numerous investigations reported $F W$ reduction in plants under water deficit, e.g. wheat [47], pearl millet [48], Abelmoschus esculentum [49] and 5 sunflower varieties [50].

Potential biomass productions vary widely for plants grown in stressful conditions. In both sunflower lines, water stress affected in a greater proportion shoot $D W$ than root $D W$. Coincidentally, a study with sugar beet genotypes demonstrated that mild water stress affected shoot $D W$ more than root $D W$ under severe stress [51]. 
Table 1. Effects of different conditions assayed on chlorophyll and carotenoids content. Values with the same letter are not significantly different at $P \geq 0.05$.

\begin{tabular}{|c|c|c|c|c|c|c|}
\hline & B59 & & & B59 & & \\
\hline Condition & Chlorophyll a & Chlorophyll b & Carotenoids & Chlorophyll a & Chlorophyll b & Carotenoids \\
\hline Control & $74.1 \pm 6.9 \mathbf{a}$ & $32.2 \pm 3.7 \mathbf{a}$ & $106.7 \pm 13.3 \mathbf{a}$ & $163.1 \pm 3 \mathbf{a}$ & $89.7 \pm 5.8$ ac & $793.3 \pm 94 \mathbf{a}$ \\
\hline Stressed & $116.8 \pm 16.4 \mathbf{b}$ & $83.4 \pm 5.2 \mathbf{b}$ & $153.3 \pm 18.6 \mathbf{b c}$ & $76 \pm 3.4 \mathbf{b}$ & $51.8 \pm 14.2 \mathbf{b}$ & $655 \pm 55 \mathbf{a}$ \\
\hline$R W 3 \mathrm{~d}$ & $112.6 \pm 6.1 \mathbf{b}$ & $64.6 \pm 7.4 \mathrm{c}$ & $120 \pm 10 \mathbf{a b}$ & $135.5 \pm 9.8 \mathbf{a}$ & $104.2 \pm 24.4 \mathbf{a}$ & $703.3 \pm 147.1 \mathbf{a}$ \\
\hline$R W 8 \mathrm{~d}$ & $157.2 \pm 37.1 \mathbf{d}$ & $76.1 \pm 9.4 \mathbf{b}$ & $160 \pm 10 \mathbf{c}$ & $136.9 \pm 26.9 \mathbf{a}$ & $87.7 \pm 4.9 \mathbf{a c}$ & $740 \pm 20 \mathbf{a}$ \\
\hline
\end{tabular}

The time of re-watering seemed not to be enough to recover shoot $D W$ to control value in both lines. On the contrary, the slight root $D W$ increase in B71 line at day 8 of re-watering could allow maximizing water uptake through a greater ability of root exploration [52,53]. The $D W$ increase of B71 roots could lead to an augmented root/shoot ratio. Coincidentally, an increased root/shoot ratio was reported in maize seedlings [54] and in three varieties of sorghum under water stress [55].

Development of optimal leaf area is important to photosynthesis and dry matter yield. In B59 and B71 lines, individual leaf area was reduced significantly under moderate water stress. The higher reduction in the tolerant B71 could be a plant strategy to reduce transpiring area influencing photosynthesis activity. Similarly, water deficit stress mostly reduced leaf growth and in turn leaf areas in many plant species, such as Populus [56], soybean [57] and many other species [45].

Severe drought stress had reduced the leaf appearance rate of sunflower hybrid compared to the optimum irrigation condition [58]. On the contrary, in our study under moderate water stress and after $8 \mathrm{~d}$ of re-watering, both inbred lines were not reduced significantly the leaf appearance rate.

Water stress produces qualitative and quantitative changes in photosynthetic pigment composition depending upon the species tested $[59,60]$. At high water deficit, the chlorophyll content decreased to a significant level in sunflower plants [61] and in Vaccinium myrtillus [62]. In our study, it is important to remark that the basal chlorophyll content was higher in the tolerant line than in the sensitive one. Under moderate water stress, chlorophylls content declined in B71 strongly affected by the individual leaf area. Surprisingly, the sensitive B59 also decrease the individual leaf area without declining chlorophylls content under moderate water stress.

High carotenoids content has also been reported following abiotic stress $[63,64]$, and these compounds form a key part of the plant antioxidant system [65]. They play a multitude of functions in plant oxidative stress tolerance, absorbing light and transferring it to the chlorophylls, protecting the photosynthetic apparatus by quench- ing harmful free radicals, and being important in the assembly and stability of light harvesting complex proteins $[66,67]$. The high content of carotenoids in control and stressed seedlings of the tolerant B71 line suggests that this line could be better prepared to afford stress conditions such as water deficit or oxidative stress. After $8 \mathrm{~d}$ of re-watering, pigments content reached the control value in B71 line.

Several compounds play a role in osmotic adjustment such as quaternary amines, amino acids or sugar alcohols [68]. Different varieties of a particular plant species exhibit a high degree of variation in drought tolerance [69] and a possible causal link between these responses and the differential accumulation of GB and PRO among genotypes has been proposed [70].

PRO plays a diverse role in the reduction of water potential, such as osmoprotectant, stabilization of proteins, membranes and subcellular structures, and protecting cellular functions by scavenging ROS [71,72]. Therefore, PRO has a major role in maintaining osmotic adjustment and adaptation to stress [73]. Our results showed that under water stress, the aerial and root PRO content increased in the tolerant B71 line, which contributed to osmotic adjustment by decreasing the osmotic potential. Notably, root PRO content reached the control value at 3 days of re-watering showing a fast response when stress was relieved.

GB occurs most abundantly in response to dehydration stress $[19,69,74]$. GB is abundant mainly in chloroplast where this compound is synthesized [75] and then transports to other organs [76]. In this study, GB decreased significantly in the aerial part of both lines in response to water stress indicating that this compound is not the main osmo-regulator. In sensitive B59, their content decreased in aerial part while it increased in roots, suggesting that GB accumulated in leaves may be transported to roots, where it would contribute to improving drought stress tolerance.

The differential accumulation between lines may reflect different mechanism of tolerance; the highest PRO and the lowest GB in the tolerant-line B71 coincide with [77] statement that "species that behaved as PRO accu- 
mulators contained little betaines and vice versa".

Based on our results, we demonstrated that B71 line had a greater stability of its radical fresh weight relative to the control, an important osmotic adjustment capacity in aerial part which was correlated with a significant production of proline. On the other hand, its high carotenoids amount was not modified by water stress, which contributed to the antioxidant machinery. Together, such traits would generate the possibility to produce sunflower hybrids from B71 inbred line, which may enhance the seedlings establishment in marginal agroecological conditions with frequent periods of water stress.

\section{REFERENCES}

[1] J. Roche, T. Hewezi, A. Bouniols and L. Gentzbittel, "Real-Time PCR Monitoring of Signal Transduction Related Genes Involved in Water Stress Tolerance Mechanism of Sunflower," Plant Physiology Biochemical, Vol. 47, 2009, pp. 139-145.

http://dx.doi.org/10.1016/i.plaphy.2008.10.007

[2] Ş. Akıncı and D. M. Lösel, "Plant Water-Stress Response Mechanisms, Water Stress," I. Md. and M. Rahman, Eds., Water Stress, Intech Europe, 2012, pp. 15-42.

[3] S. Mahajan and N. Tuteja, "Cold, Salinity and Drought Stresses: An Overview," Archives of Biochemistry and Biophysics, Vol. 444, No. 2, 2005, pp. 139-158. http://dx.doi.org/10.1016/j.abb.2005.10.018

[4] A. K. Papadakis and K. A. Roubelakis-Angelakis, "Polyamines Inhibit NADPH Oxidase-Mediated Superoxides Generation and Putrescine Prevents Programmed Cell Death Syndrome Induced by the Polyamine Oxidase Generated Hydrogen Peroxide," Planta, Vol. 220, No. 6, 2005, pp. 826-837.

http://dx.doi.org/10.1007/s00425-004-1400-9

[5] M. Sánchez-Díaz, C. Tapia and M. C. Antolín, "Abscisic Acid and Drought Response of Canarian Laurel Forest Tree Species Growing under Controlled Conditions," Environmental and Experimental Botany, Vol. 64, No. 2, 2008, pp. 155-161. http://dx.doi.org/10.1016/j.envexpbot.2008.05.011

[6] L. Perales, V. Arbona, A. Gómez-Cadenas, M.-J. Cornejo and A. Sanz, "A Relationship between Tolerance to Dehydration of Rice Cell Lines and Ability for ABA Synthesis under Stress," Plant Physiology and Biochemistry, Vol. 43, No. 8, 2005, pp. 786-792. http://dx.doi.org/10.1016/j.plaphy.2005.07.002

[7] M. Seki, T. Umezawa, K. Urano and K. Shinozaki, "Regulatory Metabolic Networks in Drought Stress Responses," Current Opinion Plant Biology, Vol. 10, No. 3, 2007, pp. 296-302. http://dx.doi.org/10.1016/j.pbi.2007.04.014

[8] J. Dobra, V. Motyka, P. Dobrev, J. Malbeck, I. T. Prasil, D. Haisel, A. Gaudinova, M. Havlova, J. Gubis and R. Vankova, "Comparison of Hormonal Response to Heat, Drought and Combined Stress in Tobacco Plants with Elevated Proline Content," Journal of Plant Physiology, Vol. 167, No. 16, 2010, pp. 1360-1370. http://dx.doi.org/10.1016/j.jplph.2010.05.013
[9] L. Xiong, K. S. Shumaker and J. K. Zhu, "Cell Signalling during Cold, Drought and Salt Stress," Plant Cell, Vol. 14, Suppl. 1, 2002, pp. S165-S183.

[10] K. Yamaguchi-Shinozaki and K. Shinozaki, "Organization of Cis-Acting Regulatory Elements in Osmotic- and Cold-Stress-Responsive Promoters," Trends Plant Science, Vol. 10, No. 2, 2005, pp. 88-94. http://dx.doi.org/10.1016/j.tplants.2004.12.012

[11] D. Huang, W. Wu, S. R. Abrams and J. A. Cutler, "The Relationship of Drought-Related Gene Expression in Arabidopsis thaliana to Hormonal and Environmental Factors," Journal of Experimental Botany, Vol. 59, No, 11, 2008, pp. 2991-3007. http://dx.doi.org/10.1093/jxb/ern155

[12] M. M. Chaves, J. P. Maroco and J. S. Pereira, "Understanding Plant Responses to Drought from Genes to the Whole Plants," Functional Plant Biology, Vol. 30, No. 3, 2003, pp. 239-264. http://dx.doi.org/10.1071/FP02076

[13] F. M. C. Albuquerque de and N. M. de Carvalho, "Effect of Type of Environmental Stress on the Emergence of Sunflower (Helianthus annuus L.), Soyabean (Glycine $\max ($ L.) Merril) and Maize (Zea mays L.) Seeds with Different Levels of Vigor," Seed Science Technoogy, Vol. 31, No. 2, 2003, pp. 465-467.

[14] S. Ahmad, R. Ahmad, M. Y. Ashraf, M. Ashraf and E.A. Waraich, "Sunflower (Helianthus annuus L.) Response to Drought Stress at Germination and Seedling Growth Stages," Pakistan Journal of Botany, Vol. 41, No. 2, 2009, pp. 647-654.

[15] D. Talukda, "Comparative Morpho-Physiological and Biochemical Responses of Lentil and Grass Pea Genotypes under Water Stress," Journal of Natural Science, iology Medicine, Vol. 4, No. 2, 2013, pp. 396-402.

[16] M. Benešová, D. Holá, L. Fischer, P. L. Jedelský, F. Hnilička, N. Wilhelmová, O. Rothová, M. Kočová, D. Procházková, J. Honnerová, L. Fridrichová and H. Hniličková, "The Physiology and Proteomics of Drought Tolerance in Maize: Early Stomatal Closure as a Cause of Lower Tolerance to Short-Term Dehydration?" PLOS ONE, Vol. 7, No. 6, 2012, p. e38017. http://dx.doi.org/10.1371/journal.pone.0038017

[17] A. R. Lee, Y. L. Jin, W. J. Jung, J. C. Avice, A. MorvanBertrand, A. Ourry, C. W. Park and T. H. Kin, "Water-Deficit Accumulates Sugars by Starch DegradationNot by De Novo Synthesis-In White Clover Leaves (Trifolium repens)," Physiologia Plantarum, Vol. 134, No. 3, 2008, pp. 403-411. http://dx.doi.org/10.1111/j.1399-3054.2008.01156.x

[18] K. Hessini, J. P. Martinez, M. Gandour, A. Albouchi, A. Soltani and C. Abdelly, "Effect of Water Stress on Growth, Osmotic Adjustment, Cell Wall Elasticity and Water-Use Efficiency in Spartina alterniflora," Environmental and Experimental Botany, Vol. 67, No. 2, 2009, pp. 312-319. http://dx.doi.org/10.1016/j.envexpbot.2009.06.010

[19] M. Ashraf and M. R. Foolad, "Roles of Glycine Betaine and Proline in Improving Plant Abiotic Stress Resistance," Environmental and Experimental Botany, Vol. 59, 2007, pp. 206-216. http://dx.doi.org/10.1016/j.envexpbot.2005.12.006 
[20] M. Hussain. M. A. Malik, M. Farooq, M. Y. Ashraf and M. A. Cheema, "Improving Drought Tolerance by Exogenous Application of Glycinebetaine and Salicylic Acid in Sunflower," Journal of Agronomy and Crop Science, Vol. 194, No. 3, 2008, pp. 193-199. http://dx.doi.org/10.1111/j.1439-037X.2008.00305.x

[21] S. A. Anjum, M. F. Saleem, L. C. Wang, M. F. Bilal and A. Saeed, "Protective Role of Glycinebetaine in Maize against Drought-Induced Lipid Peroxidation by Enhancing Capacity of Antioxidantive System," Australian Journal of Crop Science, Vol. 6, No. 4, pp. 576-583.

[22] S. A. Anjum, X. Xie, L. Wang, M. F. Saleem, C. Man and W. Lei, "Morphological, Physiological and Biochemical Responses of Plants to Drought Stress," African Journal of Agricultural Research, Vol. 6, No. 9, 2011, pp. 20262032.

[23] D. Villadsen, J. H. Rung and T. H. Nielsen, "Osmotic Stress Changes Carbohydrate Partitioning and Fructose2,6-bisphosphate Metabolism in Barley Leaves," Functional Plant Biology, Vol. 32, No. 11, 2005, pp. 10331043. http://dx.doi.org/10.1071/FP05102

[24] Q. Zhang, J. W. Chen, B. G. Li and K. F. Cao, "The Effect of Drought on Photosynthesis in Two Epiphytic and Two Terrestrial Tropical Ferm Species," Photosynthetica, Vol. 47, No. 1, 2009, pp. 128-132. http://dx.doi.org/10.1007/s11099-009-0020-9

[25] S. Q. Yang, G. X. Ren, G. H. Yang, Y. Z. Feng and Q. Zhang, "Effects of Water Stress on Osmoregulation Substances and Chlorophyll Fluorescent Parameter for Forage Grass," Acta Botanica Boreali-Occidentalia Sinica, Vol. 27, No. 9, 2007, pp. 1826-1832.

[26] T. Mahmood, M. Ashraf and M. Shahbaz, "Does Exogenous Application of Glycinebetaine as a Pre-Sowing Seed Treatment Improve Growth and Regulate Some Key Physiological Attributes in Wheat Plants Grown under Water Deficit Conditions?" Pakistan Journal of Botany, Vol. 41, No. 2, 2009, pp. 1291-1302.

[27] M. A. Khan, M. U. Shirazi, M. A. Khan, S. M. Mujtaba, E. Islam, E. S. Mumtaz, A. Shereen, R. U. Ansari and M. Y. Ashraf, "Role of Proline, K/Na Ratio and Chlorophyll Content in Salt Tolerance of Wheat (Triticum aestivum L.)," Pakistan Journal of Botany, Vol. 41, No. 2, 2009, pp. 633-638.

[28] M. S. Rahman, H. Miyake and Y. Takeoka, "Effects of Exogenous Glycine-Betaine on Growth and Ultra-Structure of Salt-Stressed Rice Seedlings (Oryza sativa L.)," Plant Production Science, Vol. 5, 2002, pp. 33-44. http://dx.doi.org/10.1626/pps.5.33

[29] N. Iqbal, M. Ashraf and M. Y. Ashraf, "Glycinebetaine, an Osmolyte of Interest to Improve Water Stress Tolerance in Sunflower (Helianthus annuus L.): Water Relations and Yield," South African Journal of Botany, Vol. 74, No. 2, 2008, pp. 274-281. http://dx.doi.org/10.1016/j.sajb.2007.11.016

[30] A. A. Abou El-Yazied, "Foliar Application of Seed Production and Quality of Common Bean (Phaseolus vulgaris L.) under Water Stress Conditions," Research Journal of Agriculture and Biological Sciences, Vol. 7, No. 4, 2011, pp. 357-370.
[31] H. Mazahery-Laghab, F. Nouri and H. Z. Abianeh, "Effects of the Reduction of Drought Stress Using Supplementary Irrigation for Sunflower (Helianthus annuus L.) in Dry Farming Conditions," Pajouhesh va Sazandegi in Agronomy and Horticulture, Vol. 59, 2003, pp. 81-86.

[32] M. C. Baloğlu, M. Kavas, G. Aydin, H. A. Öktem and A. M. Yücel, "Antioxidative and Physiological Responses of Two Sunflower (Helianthus annuus) Cultivars under PEGMediated Drought Stress," Turkish Journal of Botany, Vol. 36, No. 6, 2012, pp. 707-714.

[33] A. A. Schneiter, "Non-Destructive Leaf Area Estimation in Sunflower," Agronomy Journal, Vol. 70, No. 1, 1978, pp. 141-142.

http://dx.doi.org/10.2134/agronj1978.0002196200700001 $\underline{0034 x}$

[34] N. C. Turner, "Techniques and Experimental Approaches for the Measurement of Plant Water Status," Plant and Soil, Vol. 58, No. 1-3, 1981, pp. 339-366. http://dx.doi.org/10.1007/BF02180062

[35] R. Sayar, M. Mosbahi, K. Kamelie and H. Khemira, "Physiological Tests as Predictive Appreciation for Drought Tolerance in Durum Wheat (Triticum durum Desf.)," Agronomy Research, Vol. 6, No. 1, 2008, pp. 79-90.

[36] H. K. Lichtenthaler and A. R. Wellburn, "Determinations of Total Carotenoids and Chlorophylls $a$ and $b$ of Leaf Extracts in Different Solvents," Biochemical Society Transactions, Vol. 11, 1983, pp. 591-592.

[37] C. Magné and F. Larher, "High Sugar Content of Extracts Interferes with Colorimetric Determination of Amino Acids and Free Proline," Analytical Biochemistry, Vol. 200, No. 1, 1992, pp. 115-118. http://dx.doi.org/10.1016/0003-2697(92)90285-F

[38] C. M. Greive and S. R. Grattan, "Rapid Assay for Determination of Water-Soluble Quaternary Amino Compounds," Plant and Soil, Vol. 70, No. 2, pp. 303-307. http://dx.doi.org/10.1007/BF02374789

[39] M. M. Chaves, J. S. Pereira, M. L. Rodrgues, C. P. P. Ricardo, M. L. Osório, I. Carvalho, T. Faria and C. Pinheiro, "How Plants Cope with Water Stress in the Field? Photosynthesis and Growth," Annals of Botany, Vol. 89, No. 7, 2002, pp. 907-916. http://dx.doi.org/10.1093/aob/mcf105

[40] C. A. Jaleel, R. Gopi and R. Panneerselvam, "Growth and Photosynthetic Pigments Responses of Two Varieties of Catharanthus roseus to Triadimefon Treatment," Comptes Rendus Biologies, Vol. 331, No. 4, 2008, pp. 272-277. http://dx.doi.org/10.1016/j.crvi.2008.01.004

[41] F. Karam, R. Masaad, T. Sfeir, O. Mounzer and Y. Rouphael, "Evaptranspiration and Seed Yield of Field Grown Soybean under Deficit Irrigation Conditions," Agricultural Water Management, Vol. 75, No. 3, 2007, pp. 226-244. http://dx.doi.org/10.1016/j.agwat.2004.12.015

[42] S. V. Angadi and M. H. Entz, "Root System and Water Use Patterns Ofdifferent Height Sunflower Cultivars," Agronomy Journal, Vol. 94, 2002, pp. 136-145. http://dx.doi.org/10.2134/agronj2002.0136

[43] M. Ghobadia, S. Taherabadia, M. E. Ghobadia, G. R. Mohammadia and S. Jalali-Honarmanda, "Antioxidant Capacity, Photosynthetic Characteristics and Water Rela- 
tions of Sunflower (Helianthus annuus L.) Cultivars in Response to Drought Stress," Industrial Crops and Products, Vol. 50, 2013, pp. 29-38. http://dx.doi.org/10.1016/j.indcrop.2013.07.009

[44] C. A. Chimenti, J. Pearson and A. J. Hall, "Osmotic Adjustment and Yield Maintenance under Drought in Sunflower," Field Crop Research, Vol. 75, No. 2-3, 2002, pp. 235-246. http://dx.doi.org/10.1016/S0378-4290(02)00029-1

[45] M. Farooq, A. Wahid, N. Kobayashi, D. Fujita and S. M. A. Basra, "Plant Drought Stress: Effects, Mechanisms and Management," Agronomy for Sustainable Development, Vol. 29, No. 1, 2009, pp. 185-212. http://dx.doi.org/10.1051/agro:2008021

[46] M. H. Tahir and S. S. Mehid, "Evaluation of Open Pollinated Sunflower (Helianthus annuus L.) Populations under Water Stress and Normal Conditions," International Journal of Agricultura and Biology, Vol. 3, 2001, pp. 236-238.

[47] J. Rane, M. Maheshwari and S. Nagarajan, "Effect of Pre-Anthesis Water Stress Ongrowth, Photosynthesis and Yield of Six Wheat Cultivars Differing in Drought Tolerance," Indian Journal of Plant Physiology, Vol. 6, 2001, pp. 53-60.

[48] M. Kusaka, M. Ohta and T. Fujimura, "Contribution of Inorganic Components to Osmotic Adjustment and Leaf Folding for Drought Tolerance in pearl Millet," Physiologia Plantarum, Vol. 125, No. 4, 2005, pp. 474-489. http://dx.doi.org/10.1111/j.1399-3054.2005.00578.x

[49] R. M. Bhatt and N. K. Srinivasa Rao, "Influence of Pod Load Response of Okra to Water Stress," Indian Journal of Plant Physiology, Vol. 10, No. 1, 2005, pp. 54-59.

[50] P. Manivannan, C. A. Jaleel, B. Sankar, A. Kishorekumar, R. Somasundaram, G. M. Alagu Lakshmanan and R. Panneerselvam, "Growth, Biochemical Modifications and Proline Metabolism in Helianthus annuus L. as Induced by Drought Stress," Colloids Suraces B: Biointerfaces, Vol. 59, No. 2, 2007, pp. 141-149. http://dx.doi.org/10.1016/j.colsurfb.2007.05.002

[51] R. Mohammadian, M. Moghaddam, H. Rahimian and S. Y. Sadeghian, "Effect of Early Season Drought Stress on Growth Characteristics of Sugar Beet Genotypes," Turkisk Journal of Botany, Vol. 289, 2005, pp. 357-368.

[52] M. H. N. Tahir, M. Imran and M. K. Hussain, "Evaluation of Sunflower (Helianthus annuus L.) Inbred Lines for Drought Tolerance," International Journal of Agriculture and Biology, Vol. 3, 2002, pp. 398-400.

[53] P. E. Verslues, M. Agarwal, S. Katiyar-Agarwal, J. Zhu and J. K. Zhu, "Methods and Concepts in Quantifying Resistance to Drought, Salt and Freezing, Abiotic Stresses that Affect Plant Water Status," Plant Journal, Vol. 45, No. 4, 2006, pp. 523-539. http://dx.doi.org/10.1111/j.1365-313X.2005.02593.x

[54] X. F. Ma, T. Yu, L. H. Wang, X. Shi, L. X. Zheng, M. X. Wang, Y. Q. Yao and H. J. Cai, "Effects of Water Deficit at Seedling Stage on Maize Root Development and Anatomical Structure," The Journal of Applied Ecology (Chine), Vol. 21, No. 7, 2010, pp. 1731-1736.

[55] M. Munamava and I. Riddoch, "Response of Three Sor- ghum (Sorghum bicolor L. Moench) Varieties to Soil Moisture Stress at Different Developmental Stages," South African Journal of Plant and Soil, Vol. 18, No. 2, 2001, pp. 75-79.

http://dx.doi.org/10.1080/02571862.2001.10634407

[56] S. D. Wullschleger, T. M. Yin, S. P. DiFazio, T. J. Tschaplinski, L. E. Gunter, M. F. Davis and G. A. Tuskan, "Phenotypic Variation in Growth and Biomass Distribution for Two Advanced-Generation Pedigrees of Hybrid Poplar," Canadian Journal of Forest Research, Vol. 35, No. 8, 2005, pp. 1779-1789. http://dx.doi.org/10.1139/x05-101

[57] J. Z. Zhang, R. A. Creelman and J. K. Zhu, "From Laboratory to Field: Using Information from Arabidopsis to Engineer Salt, Cold, and Drought Tolerance in Crops," Plant Physiology, Vol. 135, No. 2, 2004, pp. 615-621. http://dx.doi.org/10.1104/pp.104.040295()

[58] E. Gholinezhad, A. Aynaband, A. H. Ghorthapeh, G. Noormohamadi and I. Bernousi, "Effect of Drought Stress on Grain Yield, Quality Traits, Phyllochron and Leaf Appearance Rate of Sunflower Hybrid Iroflor at Different Levels of Nitrogen and Plant Population," AmericanEurasian Journal of Agricultural and Environmental Sciences, Vol. 12, No. 3, 2012, pp. 306-314.

[59] R. N. Reddy, P. Lyle and G. Small, "Applications of Spectral Hole Burning Spectroscopies to Antenna and Reaction Center Complexes," Photosynthesis Research, Vol. 31, No. 3, 1992, pp. 167-194.

http://dx.doi.org/10.1007/BF00035536

[60] A. Oukarroum, G. Schansker and R. J. Strasser, "Drought Stress Effects on Photosystem I Content and Photosystem II Thermotolerance Analyzed Using Chl $a$ Fluorescence Kinetics in Barley Varieties Differing in Their Drought Tolerance," Physiologia Plantarum, Vol. 137, No. 2, 2009, pp. 188-199.

http://dx.doi.org/10.1111/j.1399-3054.2009.01273.x

[61] S. P. Kiani, P. Maury, A. Sarrafi and P. Grieu, "QTL Analysis of Chlorophyll Fluorescence Parameters in Sunflower (Helianthus annuus L.) under Well-Watered and Water-Stressed Conditions," Plant Science, Vol. 175, No. 4, 2008, pp. 565-573. http://dx.doi.org/10.1016/j.plantsci.2008.06.002

[62] M. Tahkokorpi, K. Taulavuori, K. Laine and E. Taulavuori, "After Effects of Drought-Related Winter Stress in Previous and Current Year Stems of Vaccinium myrtillus L.," Environmental and Experimenmtal Botany, Vol. 61, No. 1, 2007, pp. 85-93. http://dx.doi.org/10.1016/j.envexpbot.2007.03.003

[63] C. H. Foyer and J. Harbinson, "Oxygen Metabolism and the Regulation of Photosynthetic Electron Transport," In: C. H. Foyer and P. M. Mullineaux, Eds., Causes of Photooxidative Stress and Amelioration of Defense Systems in Plants, CRC Press, Boca Raton, 1994, pp. 1-42.

[64] J. Peñuelas and S. Munné-Bosch, "Isoprenoids: An Evolutionary Pool for Photoprotection," Trends Plant Science, Vol. 10, No. 4, 2005, pp. 166-169. http://dx.doi.org/10.1016/j.tplants.2005.02.005

[65] C. A. Jaleel, P. Manivannan, A. Wahid, M. Farooq, H. J. Al-Juburi, R. Somasundaram and R. Panneerselvam, "Drought Stress in Plants: A Review on Morphological 
Characteristics and Pigments Composition," International Journal of Agriculture and Biology, Vol. 11, 2009, pp. 100-105.

[66] A. R. Collins, "Carotenoids and Genomic Stability," Mutant Research, Vol. 475, No. 1-2, 2001, pp. 21-28. http://dx.doi.org/10.1016/S0027-5107(01)00071-9

[67] K. K. Niyogi, C. Shih, W. S. Chow, B. J. Pogson, D. Dellapenna and O. Björkman, "Photoprotection in a Zeaxanthin- and Lutein-Deficient Double Mutant of Arabidopsis," Photosynthesis Resarch, Vol. 67, No. 1-2, 2001, pp. 139145. http://dx.doi.org/10.1023/A:1010661102365

[68] S. Cherian, M. Reddy and R. Ferreira, "Transgenic Plants with Improved Dehydration-Stress Tolerance: Progress and Future Prospects," Biologia Plantarum, Vol. 50, No. 4, 2006, pp. 481-495. http://dx.doi.org/10.1007/s10535-006-0141-y

[69] M. Chen, Q. Y. Wang, X. G. Cheng, Z. S. Xu, L. C. Li, X. G. Ye, L. Q. Xia and Y. Z. Ma, "GmDREB2, a Soybean DRE-Binding Transcription Factor, Conferred Drought and High-Salt Tolerance in Transgenic Plants," Biochemical and Biophysical Research Communications, Vol. 353, No. 2, 2007, pp. 299-305.

http://dx.doi.org/10.1016/j.bbrc.2006.12.027

[70] H. Yang, P. Reichert, K. C. Abbaspour and A. J. B. Zehnder, "A Water Resources Threshold and Its Implications for Food Security," Environmental Science and Technology, Vol. 37, No. 14, 2003, pp. 3048-3054. http://dx.doi.org/10.1021/es0263689

[71] P. B. Kavi Kishor, S. Sangam, R. N. Amrutha, P. S. Laxmi, K. R. Naidu, K. R. S. S. Rao, S. Rao, K. J. Reddy, P. Theriappan and N. Sreenivasulu, "Regulation of Proline Biosynthesis, Degradation, Uptake and Transport In Higher Plants: Its Implications in Plant Growth and Abiotic Stress Tolerance," Current Science, Vol. 88, No. 3, 2005, pp. 424-438.

\footnotetext{
Abbreviations

$D W$, dry weight; $F C$, field capacity; $F W$, fresh weight; $\mathrm{GB}$, glycinebetaine; PRO, proline; QACs, quaternary ammonium compounds; $R F W$, relative fresh weight; $R W$, re-watering; $R W C$, relative water content; $T W$, weight at full turgid; $T_{\max }$, daily maximum air temperature; $T_{\min }$, daily minimum air temperature; $T_{B}$, base temperature of $6^{\circ} \mathrm{C}$.
}

[72] M. K. Nikolaeva, S. N. Maevskaya, A. G. Shugaev and N. G. Bukhov, "Effect of Drought on Chlorophyll Content and Antioxidant Enzyme Activities in Leaves of Three Wheat Cultivars Varying in Productivity," Russian Journal of Plant Physiology, Vol. 57, No. 1, 2010, pp. 87-95. http://dx.doi.org/10.1134/S1021443710010127

[73] L. Ozturk and Y. Demir, "In Vivo and in Vitro Protective Role of Proline," Plant Growth Regulation, Vol. 38, No. 3, 2002, pp. 259-264. http://dx.doi.org/10.1023/A:1021579713832

[74] A. Mohanty, H. Kathuria, A. Ferjani, A. Sakamoto, P. Mohanty, N. Murata and A. K. Tyagi, "Transgenics of an Elite Indica Rice Variety Pusa Basmati 1 Harbouring the coda Gene Are Highly Tolerant to Salt Stress," Theoretical and Applied Genetics, Vol. 106, No. 1, 2002, pp. 5157.

[75] D. Rhodes and A. D. Hanson, "Quaternary Ammonium and Tertiary Sulfonium Compounds in Higher Plants," Annual Review of Plant Physiology and Plant Molecular Biology, Vol. 44, 1993, pp. 357-384.

http://dx.doi.org/10.1146/annurev.pp.44.060193.002041

[76] P. Mäkelä, K. Jokinen, M. Kontturi, P. Peltonen-Sainio, E. Pehu and S. Somersalo, "Foliar Application of Glycinebetaine-A Novel Product from Sugar Beet-As an Approach to Increase Tomato Yield," Industrial Crops and Products, Vol. 7, No. 2-3, 1998, pp. 139-148. http://dx.doi.org/10.1016/S0926-6690(97)00042-3

[77] R. Tipirdamaz, D. Gagneul, C. Duhazé, A. Aínouche, C. Monnier, D. Özkum and F. Larher, "Clustering of Halophytes from an Inland Salt Marsh in Turkey according to Their Ability to Accumulate Sodium and Nitrogenous Osmolytes," Environmental and Experimental Botany, Vol. 57, No. 1-2, 2006, pp. 139-153. http://dx.doi.org/10.1016/j.envexpbot.2005.05.007 